Int. J. Dev. Biol. 52: 279-286 (2008)

doi: $10.1387 / \mathrm{ijdb} .072323 \mathrm{ak}$

\title{
The Australian lungfish (Neoceratodus forsteri) - fish or amphibian pattern of muscle development?
}

\author{
AGATA KACPERCZYK and MALGORZATA DACZEWSKA* \\ Department of General Zoology, Zoological Institute, University of Wroclaw, Wroclaw, Poland
}

\begin{abstract}
The Australian lungfish Neoceratodus forsteri (Dipnoi-Sarcoterygians) is a likely candidate for the extant sister group of Tetrapoda. Transmission electron and light microscopy analysis revealed that the arrangement of somite cells of the lungfish resembles the structure of the urodelan somite. On the other hand, the pattern of early muscle formation in $N$. forsteri is similar to that found in the Siberian sturgeon (Acipenser baeri). During the early stages of myogenesis of $\boldsymbol{N}$. forsteri, somite-derived cells fuse to form multinucleated muscle lamellae. During later stages, mononucleated undifferentiated cells are first observed in the intermyotomal fissures and subsequently in the myotomes, among white muscle lamellae. The cells from the intermyotomal fissure differentiate into fibroblasts. The cells which have migrated into the myotomes, differentiate into mesenchyme-derived myoblasts. After hatching, white muscle lamellae are successively converted into polygonal muscle fibres. Conversion of lamellae into fibres may occur through splitting of muscle lamellae, or cylindrical muscle fibres may arise de novo as a result of fusion of mesenchyme-derived myoblasts. No increase in the number of muscle fibre nuclei is observed either in embryonic or juvenile musculature of $\boldsymbol{N}$. forsteri. We suggest that until the 53 stage of embryonic development, the increase in muscle mass is accomplished mainly through hyperplasy. Thus, lungfish muscle represents the organizational intermediate between fishes and amphibians. This makes it a useful model to study the evolutionary implications of the mechanisms of muscle development.
\end{abstract}

KEY WORDS: lungfish, myogenesis, mesenchymal cell, muscle lamella, muscle growth

\section{Introduction}

In all vertebrates, the paraxial mesoderm is divided into somites. In lower vertebrates (fishes and amphibians), major part of the somite consists of myotomal cells called primary myoblasts. These cells differentiate in situ into trunk (myotomal) muscles. Muscle growth occurs through both hypertrophy (muscle fibre enlargement) and hyperplasy (addition of new fibres). The mechanisms regulating hyperplasia and hypertrophy in muscle growth of fishes are still largely unknown. Most researchers believe that myosatellite cells are involved in both types of growth. These cells, first described by Mauro (1961), retain ability to divide mitotically and have a large heterochromatic nucleus, and a small amount of cytoplasm which, apart from free ribosomes and polysomes, contains only few organelles (Koumans et al., 1990). Myosatellite cells are located outside the muscle fibre sarcolemma but beneath the basal lamina which overlies the muscle fibre. Myosatellite cells are quiescent in adult muscle, but act as a reserve population of cells, which is capable of proliferation in response to injury, causing regeneration (Cossu et al., 1980; Bischoff, 1994). It is very likely that the number of fibers can increase through fibre splitting (Patterson and Goldspink, 1976). During teleost myogenesis two phases of muscle growth, named "stratified" and "mosaic" hyperplasia, have been distinguished. During the "stratified" hyperplasia additional fibres are added from discrete germinal zones of the ventral and dorsal extremes of developing myotome. The "mosaic" hyperplastic growth is manifested, in transverse sections through the embryo, by the apearance of new fibres of different age (and diameter) throughout the myotome. This type of hyperplasia occurs in fishes which grow to a large ultimate size (Rescan, 2005). In contrast to birds and mammals, where generally the increase in the number of muscle fibres stops shortly after birth (Goldspink, 1972), in fishes hyperplasia remains important for the long time past the juvenile stage (Greer-Walker, 1970; Stickland, 1983).

Formation of embryonic muscle fibres differs between teleosts

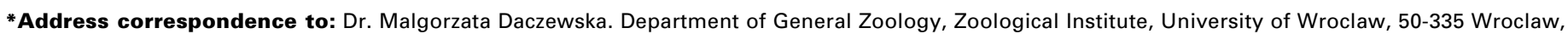
Sienkiewicza 21, Poland. Tel: +48-71-322-2817. e-mail: daczew@biol.uni.wroc.pl

Published online: 14 February 2008

$0214-6282 / 2008 / \$ 35.00$

(C) UBC Press

Printed in Spain 
and chondrosteand. In Chondrostei (Acipenseridae), myoblasts derived from the somite fuse to form multinucleated muscle lamellae (flattened form of muscle fibres), whereas in teleosts, such as pike (Esox lucius) (Kacperczyk and Daczewska, 2006), European grayling ( Thymallus thymallus), (Merkel, 1995), zebrafish (Brachydanio rerio), (Waterman, 1996, after Johnston, 2001) and European pearlfish (Rutilus frisii meidinger) (Stoiber and Sänger, 1996), myoblast fusion results in formation of mutinucleated muscle fibres (Daczewska, 2006). However, there are also some differences in embryonic muscle fibre formation between fishes and amphibians. In amphibians, myotomal cells either differentiate into mononucleate, morphologically and functionally mature myotubes, or myoblasts fuse to form multinucleate myotubes (Daczewska and Palucka, 1999; Daczewska and Kielbowna, 2000; Daczewska, 2001; Kielbowna and Daczewska, 2005).

The Australian lungfish (Neoceratodus forster) is a member of Dipnoi: a sarcopterygian family Ceratodontidae. The most recent palaeontological, molecular and morphological evidence supports the position of the lungfish as the closest living relative of tetrapods. The unique phylogentic postion of the lungfish between the fishes and amphibians prompted us to analyse the differentiation of its myotomal muscle fibres. The objective of our study was to find out if the differentiation of myotomal muscles in the studied species conformed to the fish or to the amphibian pattern.

\section{Results}

\section{Differentiation of myotomal muscle fibres before hatching}

\section{Somitogenesis}

During embryogenesis of $N$. forsteri (stage 23) mesodermal blocks of cells, called somites, separate from the unsegmented mesoderm. In the sagittal section, the somite of $N$. forsteris visible as a cluster of cells arranged in a "rosette", with cells directed centripetally (Fig. 1A). The somite cells are triangular and polarized (apical end facing the somite centre and base facing outside). Ultrastructural analysis revealed that the major part of the cytoplasm of these mononucleated somite cells is occupied by large nuclei, yolk platelets and lipid droplets (Fig. 1B).

\section{Muscle lammellae formation}

At stage 25 of embryonic development, as a result of mononucleated somite cell fusion, multinuclear (containg 2-3 nuclei) white muscle lamellae form. The lamellae occupy the whole length of the myotome and are perpendicular to the notochord and neural tube. Moreover, a single layer of mononucleaded cells (external cells) with strong affinity to methylene blue was present between lateral surface of the myotome (Fig. 1C). TEM analysis revealed that myofibrylogenesis started in the white muscle lamellae (Fig. 1D). The process of myoblasts fusion showed medio-lateral gradient in each myotome. First muscle lamellae were observed in the median part of the myotome at the level of notochord, whereas in its lateral part mononucleated cells were still present (Fig. 1E). At this development stage, labelling with anti-desmin antibody revealed the presence of intermediate, desmin-positive filaments under the sarcolemma of muscle lamellae (Fig. 1F).

At a later stage (stage 39) of embronal development muscle lamellae (visible in the cross section) were filled by myofibrils. In
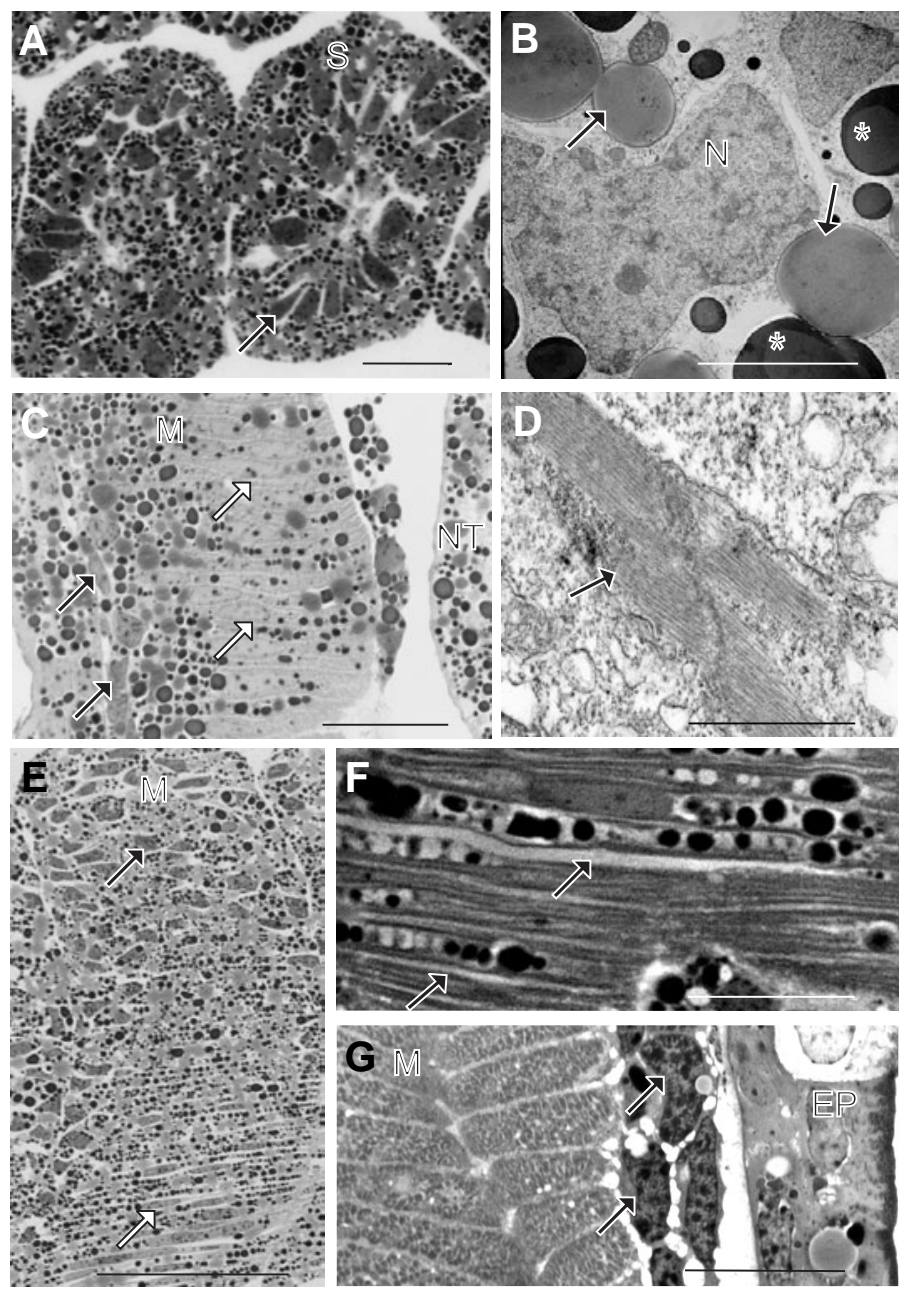

Fig. 1. Differentiation of myotomal muscle fibres before hatching.

(A) Stage 23. Somite (S), sagittal section: cells (arrow) arranged in a "rosette". Semithin section, methylene blue. Scale bar, 50 um. (B) Stage 23. Ultrastructure of somite cells. Nuclei (N), lipid yolk platelets (asterisks) and lipid droplets (arrows). Scale bar, $6 \mu \mathrm{m}$. (C) Stage 25. Cross section through the myotome. White muscle lamellae (white arrows) occupy the whole length of the myotome (M), and are perpendicular to the neural tube (NT). External cells (black arrows) in lateral part of the myotme. Semithin section, methylene blue. Scale bar, $50 \mu \mathrm{m}$. (D) Stage 25. Ultrastructure of muscle lamellae with newly formed myofibrils (arrow). Scale bar, $4 \mu \mathrm{m}$. (E) Stage 25. Sagittal section through the myotome (M). Muscle lamellae (white arrow) in medial part of the myotome; in lateral part, mononucleated, undifferentiated cells are present (black arrow).

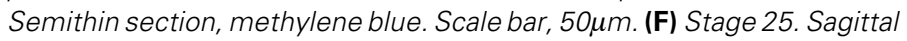
section through the myotome. Anti-desmin immunostaining. Desmin filaments (arrows) are visible under the sarcolemma of muscle lamellae. Semithin section. Scale bar, $50 \mu \mathrm{m}$. (G) Stage 39. External cells (arrows) are present between the myotome (M) and the epidermis (EP). Semithin section, methylene blue. Scale bar, $50 \mu \mathrm{m}$.

this stage of development, cells present between the myotome and the epidermis were spindle-shaped and organized into two layers (Fig. 1G). Their cytoplasm contained rough endoplasmic reticulum. These cells had characterisrtic nuclei containing electrondense chromatin beneath the nuclear envelope. Under the subepidermal connective tissue collagen fibres were observed (Fig. 2A). At this stage of development, the spindle shaped cells were the 
only cells present among the myotubes in the intermyotomal fissures and in the myotomes (Fig. 2B). Hovewer, ultrastructural analysis revealed the presence of collagen fibrils in the intermyotomal fissures (Fig. 2C).

\section{Differentiation of myotomal muscle fibres after hatching}

\section{Growth of muscles}

During later stages of myogenesis (stage 43), in the cross and sagittal sections, mononucleated undifferentiated cells of unknown origin were for the first time observed in the intermyotomal fissures and subsequently in the myotomes among the white muscle lamellae (Fig. 2D).

Ultrastructural analysis of mononucleated cells in the intermyotomal fissures showed numerous collagen fibrils in the vicinity of these cells, which confirms their mesenchymal character (Fig. 2E). In contrast, cells which had migrated into the myotomes, among the muscle lamellae, were spindle-shaped and stained more strongly with methylene blue. Their nuclei contained electron-dense chromatin under their envelope. The collagen fibres were never present in the vicinity of these cells. The plasmalemmae of the muscle lamellae and mononucleated cells closely adhered to each other. Close to the plasmalemma, in the muscle lamellae cytoplasm, numerous vesicles were present (Fig. 2F). Appearance of these structures provides an indirect morphological evidence of the fusion of these cells, as secondary myoblasts, with the myotubes.

\section{Conversion of muscle lamellae into muscle fibres}

At a further stage of myogenesis (stage 43), on cross sections of the embryo, for the first time muscle fibres of polygonal shape, closely adhering to the white muscle lamellae, were observed in the lateral part of the myotome. Between these lamellae and the muscle fibres secondary myoblasts were still present (Fig. 3A). In addition, in stage 43 an additional class of mononucleated cells, morphologically referred to as myosatellitle fibres, was observed among the white muscle lamellae and white muscle fibres. TEM analysis revealed a small number of myofibrils in the cytoplasm of myosatellitle fibres (Fig. 3B).

During later events of myogenesis (stages 44-53) the number of muscle fibres in the myotome increased concomitantly with a decreas in the length of the muscle lamellae (Fig. 3C). A diagram of ratio of the muscle lamellae and the muscle fibres in the myotome development, shows that in the consecutive development stages the white muscle lamellae are successively replaced by the polygonal muscle fibres (Fig. 4A).

TEM analysis revealed that the muscle lamellae and muscle fibres were in close contact and occupied the same space (Fig. 3D). This suggests that the muscle fibres have undergone splitting or branching off from the pre-existing musclae lamellae.

In advanced stages of myogenesis (stage 53) the whole myotome is filled with polygonal muscle fibres (Fig. 3E). Their ultrastructure reveals that myofibrils are roughly cylindrical in cross section, and are lacking the long ribbons usually found in fishes (Fig. 3F). In stage 53 of myogenesis the secondary muscle fibres of a smaller diameter, which are accompanied by the primary fibres of a larger diameter, were also present (Fig. 3E).

Cross and sagittal sections of the musculature of $N$. forsterii showed that until stage 53 (which was the last stage exmained in this study) there was no increase in the number of muscle fibre nuclei. Embryonic (stages 36-41) and juvenile (stages 43-53) musculature showed the pressence of mutinuclear (containg 2-3 nuclei only) white muscle lamellae and fibres. Moreover, until stage 53 of embryonic development, on the basis of morphological criteria, no red muscles were detected.

\section{Discussion}

\section{Early events of myogenesis}

The somites in chondrostean fishes, such as Siberian sturgeon (Aciperser baeri) (Daczewska and Saczko, 2005) and in the
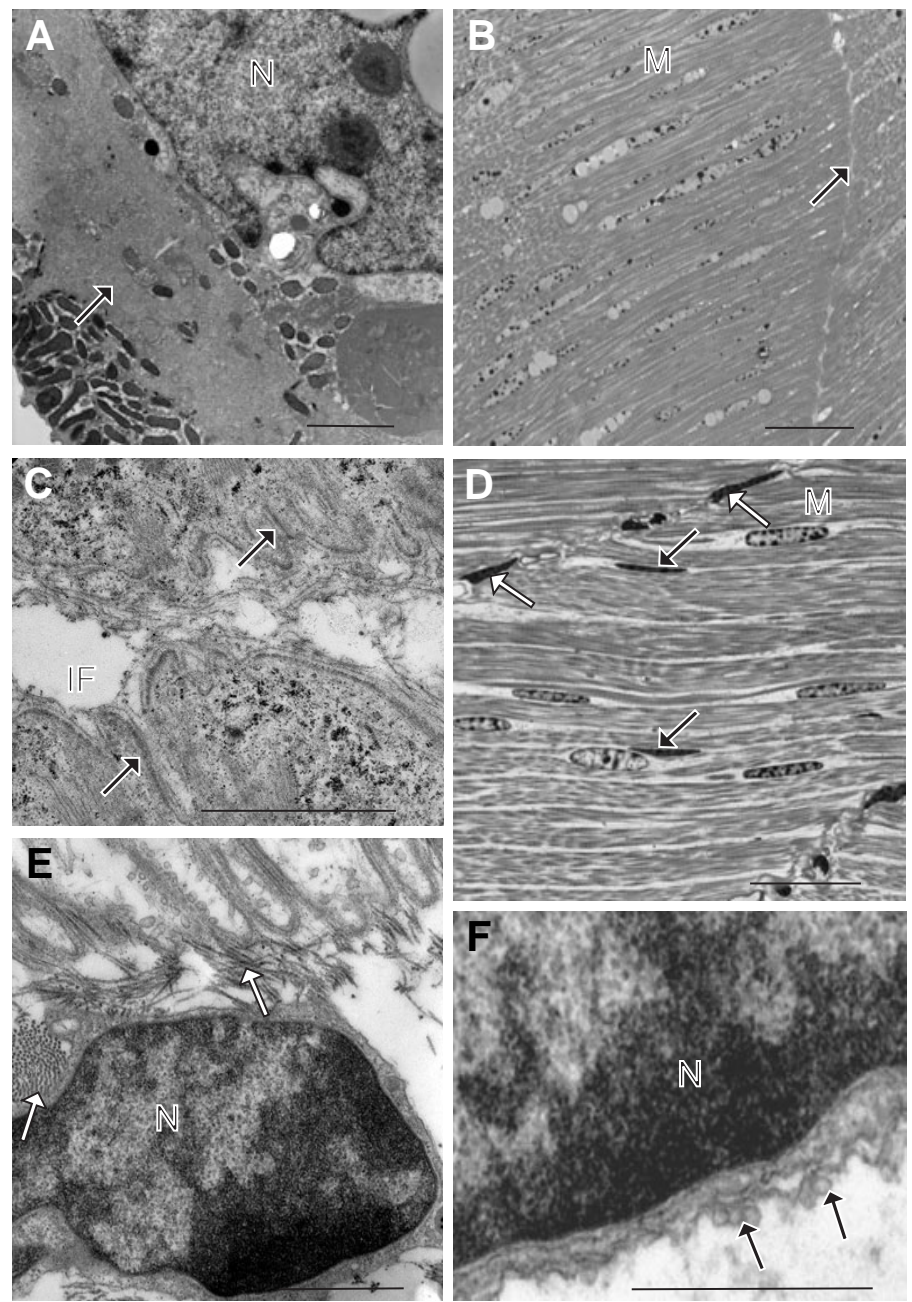

Fig. 2. Cell commitment into muscle differentiation. (A) Stage 39 Ultrastructure of external cells. Nucleus (N). Subepidermal connective tissue (arrow). Scale bar, $1.7 \mu \mathrm{m}$. (B) Stage 39. Sagittal section through the myotome (M). Intermyotomal fissures (arrow) are devoid of cellular component. Semithin section, methylene blue. Scale bar, $50 \mu \mathrm{m}$. (C) Stage 39. Collagen fibrils (arrows) in intermyotomal fissure (IF). Scale bar, $6 \mu \mathrm{m}$. (D) Stage 43. Sagittal section through the myotome (M). Mononucleated undifferentiated cells in the intermyotomal fissure (white arrows) and in the myotomes among white muscle lamellae (black arrows). Semithin section, methylene blue. Scale bar, $50 \mu \mathrm{m}$. (E) Stage 43. Ultrastructure of fibroblast in intermyotomal fissure. Fibroblast nucleus (N), collagen fibres (arrows). Scale bar, $6 \mu \mathrm{m}$. (F) Stage 43. Ultrastucture of mesenchymal secondary myoblasts. Nucleus $(N)$ is visible under sarcolemma vesicles (arrows). Scale bar, $1.1 \mu \mathrm{m}$. 

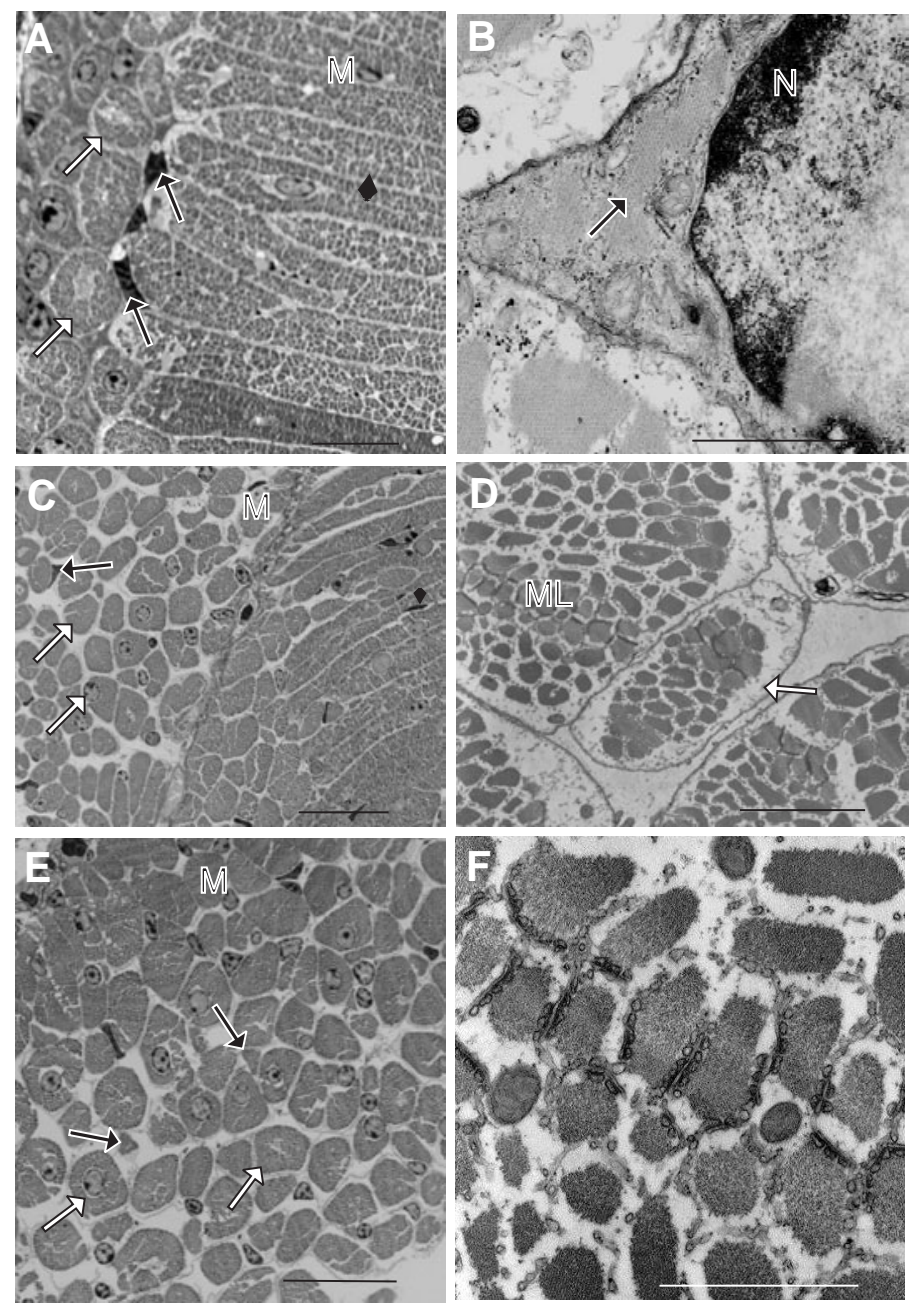

Fig. 3. Differentiation of myotomal muscle fibres after hatching. (A) Stage 43. Cross sections through the myotome (M). Polygonal muscle fibres (white arrows) closely adhere to the muscle lamellae (arrow head). Secondary myoblasts (black arrows). Semithin section, methylene blue. Scale bar, $50 \mu \mathrm{m}$. (B) Stage 43. Ultrastructure of myosatellite fibres. Nucleus (N), myofibrils (arrow) in their cytoplasm. Scale bar, $1.1 \mu \mathrm{m}$. (C) Stage 48. Cross section through the myotome (M). Polygonal muscle fibres (white arrows), muscle lamellae (arrow head). Secondary myoblasts (black arrow). Semithin section, methylene blue. Scale bar, $50 \mu \mathrm{m}$. (D) Stage 48. Polygonal muscle fibre (arrow) in close apposition to muscle lamellae (ML). TEM. Scale bar, $1.7 \mu \mathrm{m}$. (E) 18 Stage 53. Cross section through the myotome (M). Primary muscle fibres (white arrows), secondary muscle fibres (black arrows). Semithin section, methylene blue. Scale bar, $50 \mu \mathrm{m}$. (F) Stage 53. Cross sections through the muscle fibre. Ultrastructure of myofibrils. Scale bar, $1.1 \mu \mathrm{m}$.

teleosts: Th. thymallus (Merkel, 1995), B. rerio(Waterman, 1996, after Johnston, 2001), $R$. frisii meidingeri (Stoiber and Sänger, 1996), E. lucius (Kacperczyk and Daczewska, 2006), show the same structural pattern. They are built by a layer of tightly adjoining circumferential cells covering a centrally located group of more loosely arranged round cells. In contrast the somites of $N$. forsteriform a cluster of cells organized in a "rosette" configuration which is also present in urodelan embryos: axolotl ( $\mathrm{Am}$ bystoma mexicanum), sharp-ribbed salamander (Pleurodeles walti) (Youn and Malacinski, 1981) and smooth newt (Triturus vulgaris) (Daczewska and Kielbowna, 2000). There is a significant body of evidence that Dipnoi may be the living sister group of tetrapods. Studies on somitogenesis in N. forsteripresented here reveal that the somite structure in the lungfish is similar to the somite structure of urodelans rather than fishes.

The pattern of early muscle formation in $N$. forsteri is very similar to that of sturgeons - representatives of Chondrostei. During early stages of myogenesis in $N$. forsteri the somitederived stock of cells, called primary myoblasts, fuse to form multinucleated muscle lamellae. Similar muscle lamellae have been observed in early musculature of embryos of the starry sturgeon (Acipenser stellatus) and Siberian sturgeon (Acipenser baeri) (Flood and Gulyaev, 1987; Daczewska and Saczko, 2005). In these species the myotome is built of wedge-shaped, flattened multinucleate lamellae, stacked on top of each other in a dorsoventral direction. Moreover, the multinuclear muscle lamellae in sturgeons and lungfish resemble, in their structure, the mononucleated muscle lamellae present in the larval and adult musculature of amphioxus (Branchiostoma lanceolatum) (Holand et al., 1995) and in the larval musculature of Pacific lamprey (Lampetra tridentata) (Nakao, 1977).

In $N$. forsteri embryo, after the formation of white muscle lamellae, a layer of undifferentiated cells clearly separated from epidermis appears on the lateral surface of the myotome. In $N$. forsteri these cells, called "coriumblatt", were first described by Maurer (1906). They are similar to the "external cells" laterally covering the myotome, described by Waterman (1969). He believed that these cells participate in the development of dermal structures. A similar layer of cells, external to the embryonic myotome, has been found in B. lanceolatum (Maurer, 1906), L. tridentata larvae (Nakao, 1977), African clawed frog Xenopus laevis (Grimaldinet al., 2005) and European common frog (Rana temporaria)(Maurer, 1906). Recently, Devoto et al., (2006), have described morphologically and molecularly a layer of non-muscular cells on the external surface of the embryonic myotome, homologous to the amniote dermatomyotome, in fish. In $B$. rerio TEM analysis showed (Waterman, 1969) that, like in $N$. forsteri, external cells are extremely flattened. They contain rough endoplasmic reticulum, but myofibrils are lacking. A similarly structured layer of external cells was thought to contribute to slow muscle hyperplasia in post-hatching stage of the see bass (Dicentrarchus labrax) (Vegetti et al., 1990; Ramirez-Zarzoza et al., 1995), roach (Rutilus rutilus), Danube bleak (Chalcalburnus chalcoides) (Stoiber, 2002), and gilthead sea bream (Lampetra tridentata) (Ramirez-Zarzoza et al., 1995).

\section{Cells involved in myotomal muscle growth}

We observed, for the first time, that in $N$. forsteri, after hatching, the intermyotomal fissures and the myotomes among the white muscle lamellae, contain an additional class of mononucleated cells of unknown origin. Cells remaining in the intermyotomal fissures differentiate into fibroblasts with well developed collagen fibres in their vicinity. In contrast, cells, which via the myosepts, had migrated into the myotomes among the white muscle lamellae, differentiate into mesenchyme-derived muscle cells, precursors of secondary myoblasts. Their morphological characteristics (spindle-shape, heterochromatic nucleus, small amount of cytoplasm), resemble myosatellite cells, described in a wide range of fish species: B. rerio (Waterman, 1969), European eel (Anguilla 
anguilla) (Wiliamse and van der Berg, 1978), Atlantic hagfish (Myxine glutinosa) (Sandset and Korneliussen, 1987), D. labrax (Vegetti etal., 1990), Atlantic herring (Clupea harengus)(Johnston, 1993) and common carp (Cyprinus carpio) (Koumans et al., 1994), rainbow trout (Oncorhynchus mykiss) (Greenlee et al., 1995). In fish myogenesis, these cells participate in hypertrophic growth, undergoing fusion with already existing fibres, contributing to the increase in the number of nuclei in the muscle fibres, and in hyperplastic growth, they fuse with one another to form new fibres (Stickland, 1983, Koumans et al., 1993 after Johnston, 2001).

In fishes, the first myosatellite cells observed during early development are not included beneath the basal lamina (Koumans et al., 1993), which at that time, is still developing. It is has been found that in fishes, precursors of satellite cells are capable of migration during early muscle development (Devoto et al., 1996, Stoiber and Sänger, 1996 after Johnston, 2001).

We believe that in $N$. forsteri, the correlation between the appearance of mesenchyme-derived muscle cells, precursors of secondary myoblasts and formation of secondary muscle fibres, provides indirect support for the hypothesis, that these cells participate in hyperplastic growth of muscles, fusing with each other to form new secondary muscle fibres.

Morphological evidence for the myoblastic function of mesenchymal cells in $N$. forsteri, is the presence of numerous vesicles which bud off from the myotube sarcolemma, at the region of contact between the two cells. According to Orlov et al., (1989), the fusion-associated vesicles are always present below the plasmalemma of more advanced myogenic cells (Loesser et al., 1997). In fishes, fusion-associated vesicles have been observed during myogenesis in O. mykiss (Nag and Nurse, 1972), $M$. glutinosa (Sandset and Konrneliussen, 1978) and Th. thymallus (Merkel, 1995), E. lucius (Kacperczyk and Daczewska, 2006). Fusion-associated vesicles have been also found under the plasma membrane in the satellite cells of the sonic muscle in toadfish (Opsanus tau) (Loesser' et al., 1997).

The origin of satellite cells which participate in muscle growth is still controversial. Gros et al., (2005) have shown that in chicken embryos the dorsal compartment of the somites, the dermatomyotome, is the source of population of myogenic progenitors that participate in the formation of embryonic and fetal skeletal muscles. Long-term lineage analysis shows that satellite cells, which are the progenitors of adult skeletal muscles, derive from the same cell population. The authors conclude that the somite is the source of the muscle stem cell population that arises from the dermatomyotome and contributes to embryonic and adult muscle growth. Recently, Devoto et al., (2006), have shown that in sturgeon sterlet (Acipenser ruthenus), Pax 7 antibody labels nuclei in the flattened cells on the external surface of the somite, suggesting that the sturgeon external cells include myogenic precursors. Also in $B$. rerio, Pax 7 antibody labels the nuclei of cells on the somite surface (Devoto et. al., 2006). During muscle differentiation in $N$. forsterimesenchymal cells with myoblastic potential invade the already differentiated myotome filled with post-mitotic multinucleate muscle lamellae. Consequently, in this species, the myotome can be excluded as the source of mesenchymal cells of myogenic potential. The source of mesenchymal cells in many species described above is usually located in the external part of the myotome; it seems that also in N. forsteri external cells may be a source of muscles progenitors.

\section{Conversion of muscle lamellae into muscle fibres}

Similar to sturgeons $A$. baeri and $A$. stellatus (Flood and Gulyaev, 1987; Daczewska and Saczko, 2005), in N. forsteri, after hatching, the white muscle lamellae are successively converted into white muscle fibres. At advanced stages of myogenesis, the whole musculature of $N$. forsteri, like that of sturgeons, contains muscle fibres. In $A$. stellatus, multinucleated muscle lamellae undergo divisions leading to the formation of multinucleated muscle fibres (Flood and Gulyaev,1987). In N. forsteri TEM analysis reveals that muscle lamellae and muscle fibres are in close contact and occupy the same space. According to Banker and Engel (1994), when two muscle fibres in close apposition occupy the same space, they probably had undergone splitting or branching.

Fibre division occurs in adult specimens of cod icefishes (Notothenia coriiceps and Patagonotothen longipes), leading to a slight increase (1-3\%) in fibre number and muscle mass (Johnston et al., 2003). Fibre splitting has also been found to occur in the coalfish (Gadus virens) (Patterson and Goldspink, 1976), mullet (Mugil cephalus) (Carpene and Vegetti, 1981) and $A$. anguilla (Wiliemse and Leiuma-Noordanaus, 1984).

\section{Muscle growth}

In fishes, growth of skeletal muscle occurs through both hyperplasia (formation of new muscle fibres) and hypertrophy (growth of pre-existing muscle fibres). In $N$. forsteri during the embryogenesis, before and after hatching, no increase in the number of muscle fibres is observed, whereas within the large mass of white muscle there are small-diameter fibres which give the muscle a mosaic appearance. It is commonly accepted that in fish species of large ultimate size, like red seabream (Pagrus major) (Matsuoka and Iwai, 1984), Atlantic salmon (Salmo salar) (Stickland et al., 1988), D. labrax (Vegetti et al., 1990), European plaice (Pleuronectes platessa) (Brooks and Johnston, 1993), $S$. aurata (Mascarello et al., 1993) and also $N$. forsteri, the muscle mass grows mainly through addition of new fibres (Koumans and Akster, 1995). In $N$. forsteri, the appearance of mesenchymederived secondary myoblasts (myosatellitle cells) and the splitting of pre-existent larger muscle lamellae coincide with the

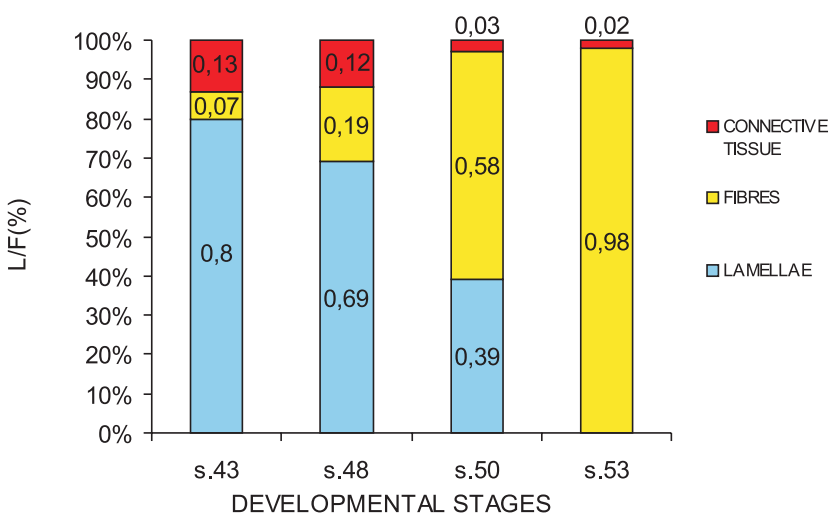

Fig. 4. Conversion of muscle lamellae into muscle fibres. Histogram of muscle lamella/plygonal muscle fibre ratio during development. (L/F\%). 
appearance of new, small (secondary) white muscle fibres. Thus we postulate that in $N$. forsteriboth the satellite cells and the splitting of the fibres are the mechanism underlying hyperplasia. No increase in the number of muscle fibre nuclei is observed in either embryonic or juvenile musculature of $N$. forsteri, which indicated that, during studied developmental stages, the increase in muscle mass is accomplished mainly through hyperplasia.

\section{Morphology of adult muscles}

In $N$. forsteri, at advanced stages of myogenesis (stage 53 ), basing on morphological criteria, no red musle fibres are observed. However, in adult musulature of African lungfish (Protopterus aethiopicus), a small number of red muscle has been found along the lateral line (Dunn et al., 1981). Like other fishes, lungfish primarily uses gills to breathe. During periods of drought, it can tolerate stagnant conditions thanks to breathing the air because it supplements the respiration using a modified swim bladder (lung) (Berra, 2001). Thus, the lungfish is in a diving state when all tissues may potentially experience severe hypoxia (Dunn etal., 1981). The very low mitochondrial density, capillarity, and lipid content in muscle fibres of lungfishes, the low number of red muscle, and its low aerobic capacity, indicate that the whole muscle structure is adapted to anaerobic function (Dunn et al., 1981).

Ultrastructural examination of $N$. forsteri, like in $P$. aethiopicus, reveals that myofibrils are roughly cylindrical in cross section, and are lacking the long ribbons which are usually found in teleost fishes (Kilarski, 1967 after Dunn et al., 1981). P. aethiopicus has a muscle structure similar to that of amphibians, with the mosaic arrangement of fibres and lack of subsarcolemmal band of mitochondria located around the periphery. The muscle organization in the lungfish appears to be intermediate between fishes and amphibians and this makes it a useful model for explaining the evolutionary implications of the mechanism of muscle development.

\section{Evolutionary implications}

In our work we show that some features of muscle development in $N$. forsteri are shared by fishes and amphibians. It is commoly accepted that tetrapods have evolved from lobe-finned fishes (Sarcopterygii). The two main groups within sarcopterygians are Dipnomorpha which include lungfishes, and Actinistia which are represented by latimerian (Zardoya and Mayer, 2003). According to Mayer, (1995), the Acantinistia lineage is not the direct source of the tetrapod lineage, but represent the lineage leading to modern lungfishes. Recent molecular and phylogenetic analyses of a nuclear gene, the myelin DM20, support the view that the lungfishes are the sister group of tetrapods (Tohyama et al., 2000 after Zardoya and Mayer, 2003). Also the presence of a single deletion in the amino acid sequence in the gene RAG2, which is shared by lungfishes and tetrapods, supports this hypothesis (Venkatesh et al., 2001). Other molecular data that support the view that lungfishes as the closest living relatives of tetrapods, are based on the similarities in their 12S rRNA and cytochrome $b$ genes (Mayer, 1995). Finally, according to Mayer, (1995), the lungfish mtDNA is more closely related to that of the frog than the coelacanth.

The evolution of fish into tetrapods is still very elusive but as more speciments are being found the path of their evolution may became more clear.

\section{Materials and Methods}

Embryos were provided by Anne Kemp, Queesland University, Australia. The study of myotomal myogenesis included the development period from stage 23 to stage 53 . Hatching took place at stage 41 . Developmental stages were determined according to the developmental table for $N$. forsteri (Semon, 1901). The egg envelopes were removed with forceps. The embryos were anaesthetized with Tricaine (MS 222) (Alpharma) and placed in fixative.

\section{Light and TEM microscopy}

Material for transmission electron microscope (TEM) analysis was fixed for $24 \mathrm{~h}$ in $4^{0} \mathrm{C}$ in modified Karnowsky's liquid $\mathrm{pH}$ 7.2: $1 \%$ paraformaldehyde (Sigma Aldrich), 1\% glutaraldehyde (Sigma Aldrich) in $0.1 \mathrm{M}$ phosphate buffer. The material was repeatedly rinsed in the same buffer and post-fixed for $2 \mathrm{~h}$ in $1 \% \mathrm{OsO}_{4}$ (Sigma Aldrich) in phosphate buffer, $\mathrm{pH}$ 7.2. Following rinsing in $0.1 \mathrm{M}$ phosphate buffer, the material was dehydrated in graded alcohol series and acetone, and embedded in epoxy resin Epon 812 (Sigma Aldrich). The Epon blocks were cut on Reichert Ultracut E ultramicrotome. Semithin sections $(0.6 \mu \mathrm{m})$ were stained with methylene blue in $1 \%$ borax solution (Sigma Aldrich) and examined in light microscope, Olympus BHS. Ultrathin sections were contrasted with uranyl acetate and lead citrate according to the standard Reynolds (1963) protocol, end examined in TEM, Zeiss EM 900 at an accelerating voltage of $80 \mathrm{kV}$.

\section{Immunocytochemistry}

The embryos were fixed in $4 \%$ paraformaldehyde, dehydrated and embedded in Histocryl (Agar Scientific Ltd., Stansted, Essex, England). The Histocryl blocks were cut on Reichert Ultracut E microtome. Standard immunocytochemical reactions were done on semithin sections $(2 \mu \mathrm{m})$. The polyclonal antibody directed against desmin (Sigma D-8281) was used at the dilution of 1:20. Secondary antibodies conjugated with FITC (Santa Cruz Biotechnology-3692) were used at 1:100 dilution. The sections were examined under a fluorescence microscope Olympus BHS.

\section{Morphometry}

All measurements were performed on semithin cross-sections $(3 \mu \mathrm{m})$, (obtained according to the procedure described above) from the level of anus. Embryos at successive developmental stages (30-53) were used for measurements.

The morphometric variables: the total area of myotome and diameter of 30 muscle lamellae and muscle fibres, both in epaxial and hypaxial parts of the myotome, were measured using a Zeiss Axioskop 20 Microscope with KS100 software.

The data were subjected to variance analysis (two way ANOVA). The normal distribution was verified with quanntile diagrams and homogeneity of variances within groups - using Brown-Forsythe Test $(p=0.071)$.

\section{Acknowledgements}

The authors thank DrA. Kemp from University of Queensland (Australia) for providing the embryos of N. forsteri, and Ms. K. Pajer, Ms. S. Nowak and Mr. W. Balazs for their technical assistance. We acknowledge the support of the MYORES project (511978), funded by the EC's Sixth Framework Programme and by the Polish State Committee for Scientific Research (KBN), Project No 2020/W/IZ/2006.

\section{References}

BANKER, B.Q. and ENGEL, A.G. (1994). Basic reactions of muscle. Myology, 2nd ed. Engel AG, Franzini-. Armstrong C. New York: McGraw-Hill. 832-888. 
BERRA, T.M. (2001). Freshwater Fish Distribution. San Diego CA: Academic Press.603-604.

BISCHOFF, R. (1994). The satellite cells and muscle regeneration in Myogenesis. Engel A.G, Fransini-Amstrong C., Eds. 2. New York: McGraw-Hill. 97-118.

BROOKS, S. and JOHNSTON, I. A. (1993). Influence of development and rearing temperature on the distribution, ultrastructure and myosin sub-unit composition of myotomal muscle fibre types in the plaice Pleuronectes platessa. Mar. Biol. 117: $501-513$.

CARPENÉ, E. and VEGETTI, A. (1981). Increase in muscle fibres in the lateralis muscle (white portion) of Mugilidae (Pisces, Teleostei). Experientia 37: 191193.

COSSU, G., ZANI, B., COLETTA, M., BOUCHE, M., PACIFICI, M., MOLINARO, M. (1980). In vitro differentiation of satellite cells isolated from normal and dystrophic mammalian muscles. A comparison with embryonic myogenic cells. Cell Differ. 9: 357-368.

DACZEWSKA, M. and PALUCKA, M. (1999). Development of primary and secondary muscle fibres in the muscle fibres in the myotomes of Rana Lessonae (Anura:Ranidae). Zool. Pol. 44: 59-69.

DACZEWSKA, M. and KIELBOWNA, L. (2000). Myotomal myogenesis in Triturus vulgaris $\mathrm{L}$. (Urodela) with special reference to the role of mesenchymal cells. Folia Biol. (Krakow) 48: 37-42.

DACZEWSKA, M. (2001). Mechanism of multinucleate myotomal muscle fibre formation in Hymenochirus boettegeri(Anaura, Pipidae). Zoomorphology 121: 27-36.

DACZEWSKA, M. and SACZKO, J. (2005). Myotomal myogenesis of axial muscle in the sturgeon Acipenser baeri (Chondrostei, Acipenseriformes). Folia Biol. (Krakow) 53: 29-38.

DACZEWSKA, M. (2006). Comperative analysis of myotomal muscle differentiation in vertebrates with special reference to the role of mesenchymal cells. Zool. Pol. 51: 1-54.

DEVOTO, S.H., MELANCON E., EISEN, J.S., WESTERFIELD, W. (1996). Identyfication of separate slow and fast muscle precursor cells in vivo prior somit formation. Development 122: 3371-3380.

DEVOTO, S.H., STOIBER, W., HAMMOND, C.L., STEINBACHER, P., HASLETT, J.R., BARRESI, M.J., PATTERSON, S.E., ADIARTE, E.G., and HUGHES, S.M. (2006). Generality of vertebrate developmental patterns: evidence for a dermomyotome in fish. Evol. Dev. 8 (1): 101-110.

DUNN, J.F., DAVISON W., MALOIY, G.M., HOCHACHKA, P.W., GUPPY, M. (1981). An ultrastructural and histochemical study of the axial musculature in the African lungfish. Cell Tissue Res. 220 (3): 599-609.

FLOOD, R. and GULYAEV, H.K. (1987). Origin and differentiation of muscle fibre types in the trunk of sturgeon, Acipenser stellatus Pallas. Sarsia 72: 343-344.

GOLDSPINK, G. (1972). Postembryonic growth and differentiation of striated muscle. In The Structure and Function of Muscle, (de.G.H.Bourne). New York: Academic Press. 1: 179-236.

GREENLEE, A.R., KERSTEN, C.A. and CLOUD, J.G. (1995). Effects of triploidy of rainbow trout myogenesis in vitro. J. Fish Biol. 46: 381-388.

GRIMALDI, A., TETTAMANTI, G., MARTIN, B.L., GAFFIELD, W., POWNALL, M.E., HUGHES, S.M. (2005). Hedgehog regulation of superfacial slow muscle fibres in Xenopus and the evolution of tetrapod trunk myogenesis. Development 131: 3249-3262.

GROS, J., MANCEAU, M., THOMÉ, V., MARCELLE, C. (2005). A common somitic origin for embryonic muscle progenitors and satellite cells. Nature 435: 954958.

GRRER-WALKER, M. (1970). Growth and development of skeletal muscle fibres of cod (Gadus morhua). J. Cons. Perm. Int. Explor. Mer. 33: 228-244.

HOLLAND L.Z., PACE D.A., BLINK M.L., KENE M., HOLLAND N.D. (1995). Sequence and expression of amphioxus alkali myosin light chain (AmphiMLCalk) throughout development: implications for vertebrate myogenesis. Dev. Biol. 171:665-676.

JOHNSTON, I. A. (1993). Temperature influences muscle differentiation and relative timing of organogenesis at the atlantic herring (Clupea haregnus) larvae. Mar. Biol.116: 363-379.

JOHNSTON, I. A. (2001). Muscle development and growth. Edited by William S. Hoar, David J. Randall and Anthony P. Farrell. School of Environmental and
Evolutionary Biology University of St. Andrews. Academic Press. 73-263.

JOHNSTON, I. A., FERNANDEZ, D.A., CALVO, J., VIEIRA, V.L.A., NORTH, A., ABERCROMBY, M., GARLAND, T. (2003). Reduction in muscle fibre number during the adaptive radiation of notothenioid fishes: a phylogenetic perspective. J. Exp. Biol. 206: 2595 - 2609.

KACPERCZYK, A. and DACZEWSKA, M. (2006). Mixed mesodermal -mesenchymal origin of myotomal muscles in pike (Esox lucius. Teleostei). Anat. Histol. Embryol. 35: 57-65

KIELBOWNA, L. and DACZEWSKA, M. (2005). The origin of syncytial muscle fibres in the myotomes of Xenopus laevis - a revision. Folia Biol. (Krakow) 52: 1-12.

KILARSKI, W. (1967). The fine structure of striated muscles in teleosts. Z. Zellforsch. Mikrosk. Anat. 79: 562-580.

KOUMANS, J. T. M., AKSTER, H.A., DULOS, G.J., OSSE, J.W.M. (1990). Myosatellite cells of Cyprinus carpio (Teleostei) in vitro: isolation, recognition and differentiation. Cell Tissue Res. 261: 173-181.

KOUMANS, J.T.M., AKSTER, H.A., BOOMS, G.H.R., OSSE, J.W.M. (1993) Growth of carp (Cyprinus carpio) white axial muscle; hyperplasia and hypertrophy in relation to the myonucleus/ sarcoplasm ratio and the occurrence of different subclasses of myogenic cells. J. Fish Biol. 43: 69-80.

KOUMANS, J.T.M., AKSTER, A.H., WITKAM, A., OSSE, J.W.M. (1994). Number of muscle nuclei and myosatellite cell nuclei in red and white axial muscle during growth of the carp (Cyprinus carpio). J. Fish Biol. 44: 391-408.

KOUMANS, J.T.M. and AKSTER, H.A. (1995). Myogenic cells development and growth of fish. Comp. Biochem. Physiol. 110A: 3-20.

LOESSER, K.E., RAFI, J, FINE, M.L. (1997). Embryonic, juvenile, and adult development of the toadfish sonic muscle. Anat. Rec. 249 (4): $469-477$.

MASCARELLO F., ROWLERSON G., RADAELLI P., SCAPOLO A. AND VEGETTI A. (1995). Differentiation and growth of muscle in the fish Sparus aurata(L.): I. Myosin expression and organization fibre types in lateral muscle from hatching to adult. J. Muscle Res. Cell Motil. 16: 213-222.

MATSUOKA, M. and IWAI, T. (1984). Development of the myotomal musculature in the red sea bream. Bull. Jpn. Soc. Fish 50: 29 -35.

MAURER F. (1906). Die Entwickelung des Muskelsystems und der elektrischen Organe. In: Hertwig O (ed) Handbuch der vergleichenden und experimentellen Entwickelungslehre der Wirbeltiere. Gustav Fischer, Jena.

MAURO, A. (1961). Satellite cells of skeletal muscle fibres. J. Biophys. Biochem. Cytol. 9: 493 - 495 .

MAYER, A. (1995). Molecular evidence on the origin of tetrapods and the relationships of the coelacanth. Trends Ecol. Evol. 10: 111-16.

MERKEL, M. (1995). Somitogenesis and myotomal myogenesis in European grayling Thymallus thymallus (L.) (Teleostei). Zool. Pol. 40: 119-130.

NAG, A.C. and NURSE, J.R. (1972). Histogenesis of white and red muscle fibres of trunk muscles of fish Salmo gairdneri. Cytobios 6: 227-246.

NAKAO, T. (1977). Electron microscopic studies on the myotomes of larval lamprey, Lampetra japonica. Anat. Rec. 187: 383-403.

ORLOV, VS, SAMOSUDOVA, N.V., SHUNGSKAYA, V.E. (1989). Possible physicochemical mechanism of cell fusion in myogenesis of skeletal muscle by means of intercellular pinocytosis. Biophisics 34: 665-670.

PATTERSON, S. and GOLDSPINK, G. (1976). Mechanism of myofibril growth and proliferation in fish muscle. J. Cell Sci. 22: 607-616.

RAMIREZ-ZARZOZA, G., GIL, F., LATORRE, R., ORTEGA, A., GARCIA-ALCARAZ, A., ABELLAN, E., VAZQUEZ, J.M., LOPEZ-ALBORS, O. and MORENO, F. (1995). The larval development of lateral musculature in gilthead sea bream Spartus aurata and sea bass Dicentrarchus labrax. Cell Tissue Res. 280: 217224.

RESCAN, P.Y. (2005). Muscle growth patterns and regulation during fish ontogeny. Gen. Comp. Endocrinol. 142: 111-116.

REYNOLDS, E. (1963). The use of lead citrate at high $\mathrm{pH}$ as an electron-opaque stain in electron microscopy. J. Cel/ Biol. 17: 208-212.

SANDSET, P.M. and KORNELIUSSEN H. (1987). Myosatellite cells associated with different muscle fiber types in the Atlantic hagfish (Myxine g/utinosa, L.). Cell Tissue Res. 195: 17-27.

SEMON, R. (1901). Normentafel zur Entwicklungsgeschichte des Ceratodus Forsteri. Verlag von Gustav Fischer. Jena: 17-25. 
STICKLADND, N.C. (1983). Growth and development of muscle fibers in the rainbow trout (Salomo gairdner). J. Anat. 137: 323-333.

STICKLAND, N. C., WHITE, R.N., MESCALL, P.E., CROOK, A.R., THORPE, J.E. (1988). The effect of temperature on myogenesis in embryonic development of the Atlantic salmon (Salmo salarL.). Anat. Embryol. 178: 284-298.

STOIBER, W. and SÄNGER, A.M. (1996). An electron microscopic investigation into the possible source of new muscle fibres in teleost fish. Anat. Embryol. 194: 569-579.

STOIBER, W., HASLETT, J.R., WENK, R., STEINBACHER, P., GOLLMANN, H.P. and SÄNGER, A. (2002). Cellularity changes in developing red and white fish muscle at different temperatures: simulating natural environmental conditions for a temperate freshwater cyprinid. J. Exp. Biol. 205: 2349-2364.

TOHYAMA, Y., ICHIMIYA, T., KASAMA-YOSHIDA, H., CAO, Y., HASEGAWA, M. (2000). Phylogenetic relation of lungfish indicated by the amino acid sequence of myelin DM20. Brain Res. Mol. Brain Res. 80: 256-259.

WATERMAN, R. E. (1969). Development of lateral musculature in the teleost Brachydanio rerio: A fine structural study. J. Anat. 125: 457-493.
WILLEMSE, J. J. and LIEUWMA-NOORDANUS, C. (1984). The generation of new "white" muscle fibres by budding in the lateral musculature of elver Anguilla anguilla (L.). Experientia 40: 990-992.

WILLIAMSE, J.J. and VAN DEN BERG, P.G. (1978). Growth of striated muscle fibres in the m. lateralis of the European eel Anguilla anguilla (L.) (Pisces, Teleostei). J. Anat. 125: 447-460.

VEgGetTI, A., MASCARELlo, F., SCAPOLO, P.A., ROWLESON, A. (1990). Hyperplastic and hypertrophic growth of lateral muscle in Dicentrarchus labrax (L.). Anat. Embryol. 182: 1-10.

VENKATESH, B., ERDMANN, M.V., BRENNER, S. (2001). Molecular synapomorphies resolve evolutionary relationships of extant jawed vertebrates. Proc. Natl. Acad. Sci. USA. 98: 11382-11387

YOUN, B. W. and MALACINSKI, G. M. (1981). Somitogenesis in the amphibian Xenopus laevis: scanning electron microscopic analysis of intrasomitic cellular arrangements during somite rotation. J. Embryol. Exp. Morphol. 64: 23-43.

ZARDOYA, R. and MAYER, A. (2003). Recent Advances in Molecular Phylogeny of Vertebrates. Annu. Rev. Ecol. Syst. 34: 311-338.

\section{Related, previously published Int. J. Dev. Biol. articles}

See our recent Special Issue Developmental Biology in Poland edited by Kloc, Maleszewski and Tarkowski at: http://www.ijdb.ehu.es/web/contents.php?vol=52\&issue=2-3

See our Special Issue Mammalian Reproduction \& Development in honor of Anne McLaren and edited by Brigid Hogan at: http://www.ijdb.ehu.es/web/contents.php?vol=45\&issue=3

Coexpression of Notch3 and Rgs5 in the pericyte-vascular smooth muscle cell axis in response to pulp injury

Henrik Lovschall, Thimios A. Mitsiadis, Knud Poulsen, Kristina H. Jensen and Annette L. Kjeldsen Int. J. Dev. Biol. (2007) 51: 715-721

Myoskeletin, a factor related to Myocardin, is expressed in somites and required for hypaxial muscle formation in Xenopus

Hui Zhao, Martha L. Rebbert and Igor B. Dawid

Int. J. Dev. Biol. (2007) 51: 315-320

An efficient method for isolation of murine bone marrow mesenchymal stem cells

Samad Nadri, Masoud Soleimani, Reza H. HosSeni, Mohammad Massumi, Amir Atashi and Reza Izadpanah

Int. J. Dev. Biol. (2007) 51: 723-729

Enhanced development of porcine embryos cloned from bone marrow mesenchymal stem cells

Hai-Feng Jin, B. Mohana Kumar, Jung-Gon Kim, Hye-Jin Song, Yeon-Ji Jeong, Seong-Keun Cho, Sivasankaran Balasubramanian, Sang-Yong Choe and Gyu-Jin Rho

Int. J. Dev. Biol. (2007) 51: 85-90

Tbx1 is expressed at multiple sites of epithelial-mesenchymal interaction during early development of the facial complex

Maria Zoupa, Maisa Seppala, Thimios Mitsiadis and Martyn T. Cobourne

Int. J. Dev. Biol. (2006) 50: 504-510

Comparative expression analysis of $\mathrm{Pax} 3$ and $\mathrm{Pax} 7$ during mouse myogenesis

David Horst, Svetlana Ustanina, Consolato Sergi, Gregor Mikuz, Herbert Juergens, Thomas Braun and Eugene Vorobyov

Int. J. Dev. Biol. (2006) 50: 47-54

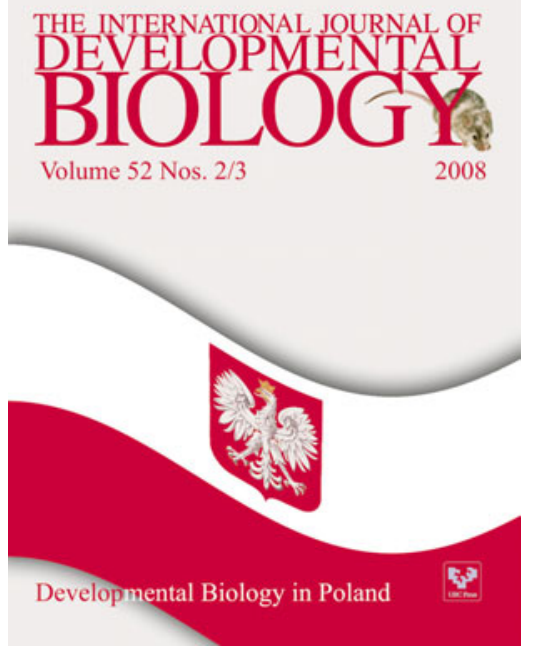

2006 ISI **Impact Factor $=3.577^{\star *}$

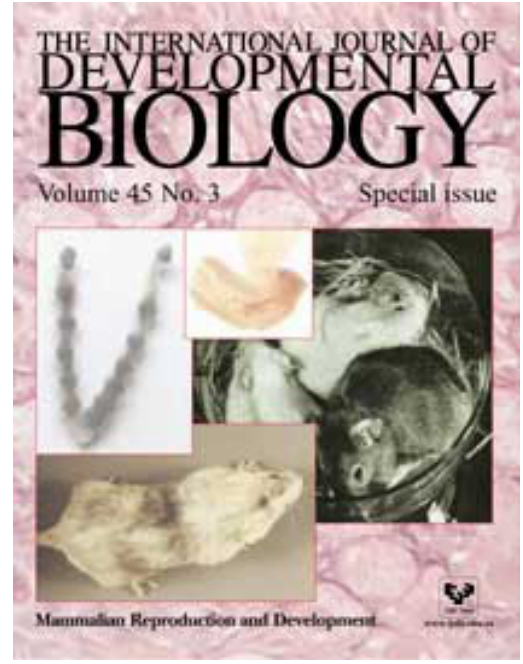

